\title{
DAMAGES FOR WRONGFUL FERTILISATION: RELIANCE ON POLICY CONSIDERATIONS
}

\section{Chen Meng Lam*}

In what was described as 'one of the most difficult cases' that had come before it, the Singapore Court of Appeal in ACB v Thomson Medical Pte Ltd ('ACB') recognised, for the first time, the loss of genetic affinity as an independent head of loss that would allow a plaintiff to recover damages in a claim for wrongful fertilisation. In $\mathrm{ACB}$, the Court of Appeal dismissed the claim for upkeep costs of raising the child from birth to maturity, and instead identified the loss of genetic affinity as the real harm for which damages should be awarded to compensate for the mistaken use of sperm from an unknown third party. An interesting aspect of ACB was how the Court of Appeal grappled with policy considerations as the basis for its decision. The influence of policy considerations in ACB raises the question of whether the decision runs contrary to the long-standing view that there is little room for public policy reasoning in private law adjudication. In this article, the author argues that the Court of Appeal's decision in ACB was correctly made as it rightly embraced policy considerations in rejecting the upkeep claim and focused on the value of biological relationships in recognising an interest in genetic affinity.

\section{INTRODUCTION}

Awarding compensation for loss of 'genetic affinity' was unprecedented until the landmark case of $A C B v$ Thomson Medical Pte Ltd ('ACB') ${ }^{1}$ in Singapore. In that case the plaintiff sued for compensation for raising a child who had not been fathered by her husband, an eventuality brought about by the defendants' negligence while carrying out an in-vitro fertilisation ('IVF') process. The

\footnotetext{
* Juris Doctor (Ohio State), Senior Lecturer, Singapore University of Social Sciences, School of Business.

${ }^{1} A C B v$ Thomson Medical Pte Ltd [2015] 2 SLR 218 (High Court) ('ACB 2015'); ACB v Thomson Medical Pte Ltd [2017] 1 SLR 918 (Court of Appeal) ('ACB 2017').
} 
Singapore High Court ${ }^{2}$ rejected the plaintiff's claim for the upkeep costs of raising the child on the basis of lack of causation between the plaintiff's loss and the defendant's negligence. ${ }^{3}$ On appeal, the Singapore Court of Appeal similarly rejected the upkeep claim, but solely on policy grounds. ${ }^{4}$ In an interesting turn, the Court of Appeal went further and created a completely new, independent category of loss - loss of genetic affinity - which reflected the lack of biological ties between the child and the parent at issue. The Court of Appeal recognised that a mother's desire to have a child of her own with her husband is a 'basic human impulse' and that 'its loss is keenly and deeply felt, even if it is difficult to put into words'. ${ }^{5}$

The outcome of $A C B$ means that parents now have a legally recognised interest in having genetic ties with their children, one that is protected under the law and compensable with damages in Singapore if violated. This article will examine the public policy considerations that were used in $A C B$ as the basis for justifying the rejection of upkeep costs and the recognition of the new tort of genetic affinity. The role of policy in $A C B$ is worthy of attention as courts in other jurisdictions, including the United Kingdom and Australia, have consistently been wary of relying on policy considerations to decide claims involving reproductive negligence. In this article, the author argues that the Court of Appeal's decision in $A C B$ was correctly made; it rightly embraced policy considerations in denying upkeep costs and recognising an interest in genetic affinity.

\section{BACKGROUND}

\section{A Facts of the Case}

The plaintiff was a Singaporean Chinese woman married to a German man of Caucasian descent. The first defendant, Thomson Medical Pte Ltd, was a private hospital. The second defendant, Thomson Fertility Centre Pte Ltd, was a fertility clinic that provided IVF services and was wholly owned by the first defendant. The third and fourth defendants were embryologists employed by

\footnotetext{
${ }^{2}$ In Singapore, the High Court is the lower division of the Supreme Court of Singapore, the upper being the Court of Appeal. The Court of Appeal is Singapore's highest judicial tribunal. For the Singapore court structure see Singapore Supreme Court, 'Structure of the Court' (Web Page) <https://www.supremecourt.gov.sg/about-us/the-supreme-court/structure-of-thecourts>.

${ }^{3} A C B 2015$ (n 1) 226-7 [15].

${ }^{4}$ ACB 2017 (n 1) 936 [24], 941 [37], 969 [101].

${ }^{5}$ Ibid 980 [127].
} 
the second defendant. The plaintiff underwent IVF and delivered a daughter, Baby P. After birth, it was noticed that Baby P's skin colour, hair and blood type were markedly different from those of the plaintiff and her husband. It was subsequently discovered that the plaintiff's egg had been wrongly fertilised with the sperm of an unknown Indian donor, instead of those of her husband. The result was that Baby $\mathrm{P}$ was of mixed Chinese-Indian, instead of Chinese-Caucasian, ethnicity. Although Baby $\mathrm{P}$ was healthy, she was in no way biologically related to the plaintiff's husband.

The first defendant pleaded guilty to a violation of section 5(1) of the Private Hospitals and Medical Clinics Act ('the Act') ${ }^{6}$ for breaching the terms of its licence to provide assisted reproduction services and was fined SGD 20,000, the maximum permitted under the Act at that time. ${ }^{7}$ Subsequently, the plaintiff sued all the defendants in negligence. In the alternative the plaintiff also sued the second defendant for breach of contract. The parties' contract included a promise to fertilise the plaintiff's egg with her husband's sperm. The plaintiff claimed damages for pain and suffering as well as mental distress arising from the mistaken use of the sperm of a third-party stranger, and the full upkeep costs of raising Baby P. The claim for upkeep costs included, among other things, the cost of enrolling Baby $\mathrm{P}$ in an international school in Beijing where the plaintiff and her husband were residing, the cost of tertiary education in Germany, necessities such as food and clothing until Baby $\mathrm{P}$ became financially self-reliant, medical and travel expenses, expenses associated with any hobbies and extra-curricular activities that Baby $\mathrm{P}$ might pursue, and the cost of employing an additional domestic helper until she started school. ${ }^{8}$

\footnotetext{
${ }^{6}$ Private Hospitals and Medical Clinics Act (Singapore, cap 248, 1999 rev ed) s 5(1).

${ }^{7} A C B 2017$ (n 1) 930 [9]. The alleged conduct in the statement of facts accompanying the charge was that the first defendant had processed two semen specimens inside one laminar hood at the same time, and had failed to ensure that the staff handling the specimens discarded the disposable pipettes that had been used after each step of processing. The lapses in procedures had contributed to the occurrence of a human error, which resulted in the mistaken use of sperm of a third-party stranger, instead of the sperm of the plaintiff's husband.

${ }^{8} A C B 2015$ (n 1) 221 [5]. The plaintiff had also initially sued the defendants for provisional damages (until such time as Baby $P$ reached 35 years of age) for any damage arising from any genetic condition or disease that Baby $\mathrm{P}$ might have inherited as a result of the unknown donor's genes. However, the plaintiff subsequently removed this claim via an amendment to the statement of claim: at 221-2 [6].
} 


\section{B Nature of the Claim}

The nature of the claim in $A C B$ was wrongful fertilisation. Specifically, such a claim arises when

assisted reproduction technology, usually IVF, is used and a claim is brought by the gestational mother ... and/or her partner in circumstances where a healthcare professional uses the wrong gametes in the fertilisation procedure or where the 'wrong' embryo is implanted in the womb of the gestational mother and carried to term. ${ }^{9}$

Wrongful fertilisation claims are to be contrasted with wrongful conception claims. The essence of the latter is that the parents never had the intention to have further children and, hence, the conception of the child is unplanned and not desired. Wrongful conception claims are typically brought by the child's parents after a sterilisation operation has been performed negligently or after the parents have been improperly advised on the outcome of the operation, resulting in the unplanned and undesired birth of the child. ${ }^{10}$ The important distinction between $A C B$ and wrongful conception cases was that the claim by the plaintiff in $A C B$ was not that she did not want a child (in which case wrongful conception would have occurred) but rather that she did not want this particular child who was born out of the negligently performed IVF. ${ }^{11}$ The essence of the plaintiff's claim in $A C B$ was that she "never planned to have this child (that is to say, the child who was born as a result of the use of the wrong genetic material) but instead planned for and desired to have a child with whom [the couple] would share genetic kinship'. ${ }^{12}$

Wrongful fertilisation claims are also different from wrongful birth claims, as the negligent medical act in the latter takes place post-conception. The gist of a wrongful birth claim is that the child's mother would have aborted the child if she had been informed early enough either that she was pregnant or that the foetus in the womb at such time had defects. ${ }^{13}$ Wrongful birth claims are typically brought by the parents and usually occur when a medical

\footnotetext{
${ }^{9}$ ACB 2017 (n 1) 940 [34].

${ }^{10}$ Ibid 937-8 [29].

${ }^{11}$ Ibid 940 [34] (emphasis added). See also Craig Purshouse, 'Autonomy, Affinity, and the Assessment of Damages: $A C B$ v Thomson Medical Pte Ltd [2017] SGCA 20 and Shaw $v$ Kovak [2017] EWCA Civ 2018' (2017) 26(4) Medical Law Review 675, 679.

${ }^{12}$ ACB 2017 (n 1) 940 [34] (emphasis in original).

${ }^{13}$ Ibid 937-8 [29]. See also Dean Stretton, 'The Birth Torts: Damages for Wrongful Birth and Wrongful Life' (2005) 10(1) Deakin Law Review 319, 320-48.
} 
professional has failed to inform the mother of her pregnancy or properly advise that the baby would be born with birth defects. ${ }^{14}$

In a general sense, however, all the above types of claims deal with the question of whether the expense associated with the unplanned and undesired birth of a child ought to be recognised as amounting to injury that is compensable under the law. ${ }^{15}$

\section{The DeCISION In ACB}

\section{A Singapore High Court}

The Singapore High Court held that the plaintiff was not entitled in law to claim damages for the upkeep costs in either contract or tort. ${ }^{16}$ The matter was heard before Choo Han Teck J. His Honour first considered and rejected the submission by the plaintiff's counsel that, had the plaintiff been told about the mistaken use of sperm, she would have been able to terminate the pregnancy, but that once the opportunity had passed, the defendants had to contemplate that someone else would be obliged to bring up Baby P. ${ }^{17}$ His Honour reasoned that this submission was a mere afterthought as the plaintiff had not pleaded her missed opportunity to abort Baby P. ${ }^{18}$ Even if the plaintiff had done so, there was no precedent or authority to support the plaintiff's claim that damages could be sought in respect of a lost opportunity to seek an abortion. ${ }^{19}$ As observed in McFarlane v Tayside Health Board ('McFarlane') (which is discussed in Part IVA below), to allow a claim for the lost

\footnotetext{
${ }^{14}$ ACB 2017 (n 1) 937-8 [29].

${ }^{15}$ Ibid. There is also another type of claim in reproductive negligence, being a 'wrongful life' claim which is made by a child for damage to him- or herself arising from the very fact of birth. This type of claim involves the child arguing that he or she should never have been born. The English courts have rejected 'wrongful life' claims because they violate the sanctity of human life: McKay v Essex Area Health Authority [1982] 1 QB 1166. See generally Stephen Todd, 'Wrongful Conception, Wrongful Birth and Wrongful Life (2005) 27(3) Sydney Law Review 525, 537-41; Penelope Watson, 'Edwards v Blomeley; Harriton v Stephens; Waller v James: Wrongful Life Actions in Australia' (2002) 26(3) Melbourne Law Review 736, 745-8.

${ }^{16} A C B 2015$ (n 1) 228 [17]. See generally Margaret Fordham, 'An IVF Baby and a Catastrophic Error: Actions for Wrongful Conception and Wrongful Birth Revisited in Singapore' (2015) Singapore Journal of Legal Studies 232.

${ }^{17}$ ACB 2015 (n 1) 223-6 [10]-[14].

${ }^{18}$ Ibid 226 [14].

${ }^{19}$ Ibid.
} 
opportunity to have an abortion would be 'going beyond what should constitute a reasonable restitution for the wrong done' ${ }^{20}$

In relation to the plaintiff's substantive argument, Choo Han Teck $\mathrm{J}$ held that the upkeep claim must fail because the plaintiff had wanted a second child all along and was prepared to incur the expenditure involved in bringing up the second child (albeit one that she would conceive with her husband's sperm). ${ }^{21}$ His Honour reiterated that 'Baby $\mathrm{P}$ was not an unwanted birth in the sense that the plaintiff mother did not want to have a baby at all. The plaintiff just wanted a baby conceived with her husband's sperm'. ${ }^{22}$ Hence, it could not be said that the plaintiff and her husband had not contemplated having to incur expenditure to raise a child. ${ }^{23}$ In effect, his Honour concluded that there was no causation between the plaintiff's loss and the defendant's negligence since the plaintiff would still have incurred upkeep costs in raising a child in the absence of negligence. ${ }^{24}$ On this basis of lack of causation, his Honour held that the plaintiff was not entitled to claim damages for upkeep costs. ${ }^{25}$

Albeit by way of obiter dictum, the High Court mentioned policy considerations. Choo Han Teck $\mathbf{J}$ expressed the view that, as a matter of public policy, upkeep costs should not be awarded. ${ }^{26}$ His Honour cited the words of Lord Millett in the House of Lords decision of McFarlane, stating that ' $[\mathrm{t}]$ here is something distasteful, if not morally offensive, in treating the birth of a normal, healthy child as a matter for compensation' ${ }^{27}$ To this, his Honour in $A C B$ added two more specific concerns. The first was the detrimental impact that an award of damages might have on Baby P's wellbeing. In his Honour's words, '[w]ere the plaintiff to succeed in her upkeep claim, whether in tort or in contract every cent spent in the upbringing of Baby $\mathrm{P}$ will remind her that it was money from a compensation for a mistake'. ${ }^{28}$ His Honour reiterated that 'Baby $\mathrm{P}$ should not ever have to grow up thinking that her very existence was a mistake'. ${ }^{29}$ The second concern was

\footnotetext{
${ }^{20}$ McFarlane v Tayside Health Board (Scotland) [2000] 2 AC 59, 105 (Lord Clyde) (House of Lords) ('McFarlane').

${ }^{21}$ ACB 2015 (n 1) 226-7 [15].

${ }^{22}$ Ibid 227 [16].

${ }^{23}$ Ibid.

${ }^{24}$ Ibid.

${ }^{25}$ Ibid 228 [17].

${ }^{26}$ Ibid 227 [16]; ACB 2017 (n 1) 933 [16]. See also Benny Tabalujan et al, Singapore Business Law (CommAsia Resources, $8^{\text {th }}$ ed, 2018) 207-8.

${ }^{27}$ ACB 2015 (n 1) 227 [16], quoting McFarlane (n 20) 111 (Lord Millett).

${ }^{28} A C B 2015$ (n 1) 227 [16].

${ }^{29}$ Ibid.
} 
that any such award of upkeep costs would contradict the concept of a parentchild relationship since a parent is obliged to maintain his or her child. ${ }^{30}$ Given that the plaintiff and her husband had accepted Baby P as their own and assumed the status of parents, they had to be taken to have accepted the responsibility of maintaining Baby $\mathrm{P}$ financially and in all other respects. ${ }^{31}$

\section{B Singapore Court of Appeal}

On appeal, the case was heard before a five-judge Singapore Court of Appeal, with the unanimous judgment delivered by Andrew Phang Boon Leong JA (Phang JA). In denying the upkeep costs, the Court of Appeal rejected the High Court's reasoning on causation and relied solely on public policy grounds as the basis for its decision. Importantly, the Court of Appeal clarified that the difficult issue of whether upkeep costs were recoverable could not be dealt with simply as a matter of causation. ${ }^{32}$ The Court of Appeal reasoned that the fundamental error in the High Court's analysis on causation was that it ignored the 'purpose for which the expenses were (and would have been incurred)'. ${ }^{33}$ According to the Court of Appeal, the plaintiff's purpose in seeking IVF was not 'to beget a child irrespective of paternity (just so that she could have an addition to "her family unit") but to have a child with her husband' ${ }^{34}$ On that basis, the Court of Appeal concluded that it could not be said that 'she or her [h] usband ever contemplated (let alone intended) having to raise a child that was not completely theirs' ${ }^{35}$

Having rejected the 'no causation' basis, the Court of Appeal had to grapple with the wide-ranging policy considerations concerning upkeep costs. Indeed, at the beginning of the $A C B$ judgment, Phang JA foreshadowed the fact that

\footnotetext{
${ }^{30}$ Ibid.

${ }^{31}$ Ibid.

${ }^{32}$ ACB 2017 (n 1) 944 [43].

${ }^{33}$ Ibid 941-2 [38] (emphasis in original). It has been argued that the Singapore Court of Appeal's reasoning with respect to causation departs from the traditional understanding of the 'but for' test under the common law: Jordan English and Mohammud Jaamae Hafeez-Baig, 'ACB v Thomson Medical Pte Ltd: Recovery of Upkeep Costs, Claims for Loss of Autonomy and Loss of Genetic Affinity: Fertile Ground for Development?' (2018) 41(3) Melbourne University Law Review 1360.

${ }^{34}$ ACB 2017 (n 1) 943-4 [41] (emphasis in original).

${ }^{35}$ Ibid. It also did not matter whether the upkeep claim was classified as an action for the recovery of pure economic loss or as one for the recovery of consequential economic loss because there is no general exclusionary rule against recovery for pure economic loss in Singapore: at 960 [82]. See also Spandeck Engineering (S) Pte Ltd v Defence Science \& Technology Agency [2007] 4 SLR 100, 129 [69]. Thus, the characterisation of the upkeep claim cannot determine its success.
} 
the decision would be much influenced by policy considerations. He was echoing the words of Griffiths LJ from the English Court of Appeal's decision in McLoughlin v O'Brian, cited in the introduction of the $A C B$ judgment, which states as follows: '[e]very system of law must set some bounds to the consequences for which a wrongdoer must make reparation ... In any state of society it is ultimately a question of policy to decide the limits of liability'. ${ }^{36}$ This is an interesting comment, showing that the Court of Appeal openly sought to rely on public policy arguments in $A C B$ to deny upkeep costs. These arguments will be explored in greater depth in Part VB below.

The Court of Appeal went further than denying compensation on policy grounds, creating a completely new, independent head of damage to compensate for the loss of genetic affinity, namely the lack of biological ties between the child and the parent at issue. In a world first, the Court of Appeal recognised the loss of genetic affinity as an independent actionable head of damage ${ }^{37}$ and a cognisable injury that should sound in damages. ${ }^{38}$ In defining the meaning of genetic affinity, the Court of Appeal observed the following:

It is, at its core, a desire for identity bounded in consanguinity. The ordinary human experience is that parents and children are bound by ties of blood and share physical traits. This fact of biological experience - heredity carries deep socio-cultural significance. For many, the emotional bond between parent and child is forged in part through a sense of common ancestry and a recognition of commonalities in appearance, temperament, and physical appearance. ${ }^{39}$

The recognition of loss of genetic affinity by the Court of Appeal is not unexpected given that the outcome of the High Court's decision had seemed unfair to the plaintiff. The High Court's rejection of the upkeep claim had failed to recognise that a substantial real harm had been done, leaving the plaintiff, who was a victim of gross medical negligence, with no remedy other

${ }^{36}$ ACB 2017 (n 1) 927 [1], quoting McLoughlin v O'Brian [1981] 1 QB 599, 623, reversed in McLoughlin v O'Brian [1983] 1 AC 410, although not on the point of policy considerations.

${ }^{37}$ ACB 2017 (n 1) 936 [24]. On the question of whether actionable damage ought to be dealt with as an issue concerning the existence of a duty of care or as a standalone requirement, the Court of Appeal clarified that so long as the policy factors are considered openly and explicitly, the same conclusion should still be reached irrespective of the approach: at 946-8 [47]-[51]. For a general discussion of duty of care owed by medical authorities, see Anthony Gray, 'The Liability of Providers of Mental Health Services in Negligence' (2015) 20(2) Deakin Law Review 221.

${ }^{38}$ ACB 2017 (n 1) 984 [135]. In ACB, the Court of Appeal ultimately declined to grant punitive damages: at 991-1013 [153]-[209]. This article does not consider the Court of Appeal's treatment of punitive damages.

${ }^{39}$ Ibid 981 [128]. 
than the damages for pain and suffering. ${ }^{40}$ The modest sum of damages for pain and suffering was in no way adequate to compensate for the real loss which the plaintiff had suffered as a result of the defendant's negligence. The Court of Appeal, however, observed that there were practical difficulties with the assessment of damages for loss of genetic affinity and that there were "no comparable precedents (whether local or foreign) against which to draw appropriate comparisons' ${ }^{41}$ The Court of Appeal eventually quantified the loss of genetic affinity as $30 \%$ of the full cost of raising Baby $\mathrm{P}$, on the basis that the amount was 'just, equitable and proportionate' on the facts of the case. $^{42}$

\section{iV ReView of Case LaW in Other Jurisdictions}

As mentioned earlier, this is the first time a court in any jurisdiction has recognised that damage to a plaintiff's interest in genetic affinity is a cognisable injury that should sound in damages. No court has previously decided an action alleging loss of genetic affinity. Accordingly, when the Court of Appeal in $A C B$ considered the rights and remedies that would apply to such a case, it had to refer to other areas of the law in reproductive negligence for an appropriate analogy. This appropriate analogy is found in wrongful conception cases because they involve difficulties similar to those raised by an action for loss of genetic affinity, particularly the subjective nature of the injury and the difficulties in assessing damages. Furthermore, because wrongful conception claims do not necessarily involve unhealthy babies, they bear a strong resemblance to wrongful fertilisation cases such as $A C B$. More importantly, both types of case involve an invasion of subjective individual preferences regarding family formation and reproductive choice.

As for claims for upkeep costs, courts have routinely declined to grant remedies for these when medical professionals are sued for negligence. ${ }^{43}$

\footnotetext{
${ }^{40} A C B 2015$ (n 1) 228 [17].

${ }^{41}$ ACB 2017 (n 1) 989 [148].

${ }^{42}$ Ibid 990 [150] (emphasis omitted).

43 Professor Dov Fox classifies the procreative wrongs that stand to be righted into three categories: 1) the imposition of an unwanted pregnancy or parenting through professional negligence (eg, through the issuing of vitamins in place of birth control pills); 2) the deprivation of a wanted pregnancy or parenting through professional negligence (eg, through foetal misdiagnosis, leading to a pregnant woman's decision to abort a wanted pregnancy; and 3) negligent conduct that thwarts choices that parents have made about the characteristics of the baby they want. The third category of procreative wrongs includes mistakes in spermsorting, gene-editing, and pre-implant genetic diagnoses. It is this third category into which a wrongful fertilisation claim such as that in $A C B$ falls. Dov Fox, 'Reproductive Negligence'
} 
Generally, policy considerations - the question of what public policy requires in the context of the case - have played an important role in the decisions, though the reliance on policy has frequently been subject to criticism (which will be further examined in Part IVA and IVB below). The policy considerations used by courts are many and varied but broadly they can be summarised as follows. First, a court may consider that an action to recover damages for the birth of a healthy child is morally wrong because the birth of a healthy child is considered a blessing, not an injury. ${ }^{44}$ Second, a court may consider that parents should not be allowed to recover damages for the 'harm' of an unwanted birth without offsetting an amount for the benefits of parenthood, ${ }^{45}$ and the difficulty of calculating such intangible benefits in monetary terms precludes recovery. ${ }^{46}$ Third, a court may consider that the recovery of upkeep costs may place an excessive burden on the medical profession and place doctors under pressure to encourage abortions in order to avoid claims for medical negligence which might arise if the child were allowed to be born. ${ }^{47}$ Finally, a court may consider that the psychological damage suffered by a child who subsequently finds out that he or she was 'unwanted' makes the recovery of damages contrary to public policy. ${ }^{48}$

Parts IVA to IVD below review the major cases involving claims of parents to recover the costs of raising a healthy child born as a result of medical negligence. While there have been many cases of wrongful conception, the only case of wrongful fertilisation (as identified by the Court of Appeal in $A C B$ ) was Andrews $v$ Keltz ('Andrews'), ${ }^{49}$ in which the subject of upkeep

(2017) 117(1) Columbia Law Review 149, 153. See also Carol Sanger, 'The Lopsided Harms of Reproductive Negligence' (2018) 118(1) Columbia Law Review Online <http://columbia lawreview.org/content/the-lopsidedharms-of-reproductive-negligence/>.

${ }^{44}$ See, eg, McFarlane (n 20) 114 (Lord Millet). It is noted that courts had, however, consistently rejected the view that even if parents suffer a loss as a result of the birth of a healthy child, they could have mitigated this damage by terminating the pregnancy or offering the baby for adoption. See $A C B$ (n 1) 961 [84]-[85], citing McFarlane (n 20) 1317 (Lord Steyn): "it is "difficult to envisage any circumstances in which it would be right" to challenge the parents' decision not to resort either to abortion or adoption'.

${ }^{45}$ See, eg, Cattanach v Melchior (2003) 215 CLR 1, 74 [199]-[201] (Hayne J) ('Cattanach').

${ }^{46}$ See, eg, ibid 56 [144] (Kirby J), 74 [200], 90 [248] (Hayne J), 129 [356] (Heydon J); McFarlane (n 20) 97 (Lord Hope).

${ }^{47}$ See, eg, Cattanach (n 45) 28 [57] (McHugh and Gummow JJ), 58 [149] (Kirby J), 106 [295] (Callinan J).

${ }^{48}$ See, eg, ibid 144 [399] (Heydon J).

49838 NYS 2d 363 (NY Sup Ct, 2007) ('Andrews'). 
costs was considered by a court in the United States (New York), albeit with a limited discussion of the issues at hand. ${ }^{50}$

\section{A United Kingdom}

In the United Kingdom, the House of Lords in McFarlane $v$ Tayside Health Board held that the upkeep costs of raising a healthy child were irrecoverable. ${ }^{51}$ McFarlane was a wrongful conception action by the parents of an unwanted but healthy child who was conceived and born after the husband was misinformed, following a failed vasectomy, that he and his wife no longer needed to use contraceptives. First, the wife claimed $£ 10,000$ for the pain, suffering and distress resulting from the unwanted pregnancy. Second, the wife and husband claimed a sum of $£ 100,000$ for the cost of bringing up the child. At first instance, Lord Gill, dismissed the action with regard to both heads of claim. The basis of Lord Gill's judgment was that 'the privilege of being a parent is immeasurable in money terms; [and] that the benefits of parenthood transcend any patrimonial loss'. ${ }^{52}$ However, the Inner House allowed a reclaiming motion and reversed Lord Gill's order, with the result that both heads of claim were recoverable on conventional principles of delict. ${ }^{53}$ On subsequent appeal, the House of Lords unanimously held that the plaintiffs were not entitled to recover upkeep costs in relation to a healthy child. As for the wife's pain, suffering and distress arising from the unwanted pregnancy, the House of Lords held that the claim was recoverable. ${ }^{54}$

Importantly, the decision in McFarlane represents a rejection of the controversial 'benefits rule'. ${ }^{55}$ This rule allows damages to be awarded for the maintenance of a child until he or she reaches majority, but requires a setoff of an amount intended to represent the benefits derived from parenthood. ${ }^{56}$

\footnotetext{
${ }^{50}$ ACB 2017 (n 1) 939-40 [33].

${ }^{51}$ McFarlane (n 20). After McFarlane, there had been a number of cases involving recovery of costs associated with raising a disabled child. In Parkinson $v$ St James and Seacroft University Hospital NHS Trust [2002] QB 266, the plaintiff was allowed to recover some of the costs of raising a disabled child, albeit that they were limited to the extra expense arising from the child's disability. In Rees $v$ Darlington Memorial Hospital NHS Trust [2004] 1 AC 309 ('Rees'), the House of Lords allowed the plaintiff to recover the additional expense associated with the difference between bringing up a healthy child and a disabled child. The decision in McFarlane was reaffirmed in Rees.

${ }^{52}$ McFarlane v Tayside Health Board [1997] SLT 211, 216.

${ }^{53}$ McFarlane v Tayside Health Board [1998] SLT 307, 308.

${ }^{54}$ McFarlane (n 20) 59-60.

${ }^{55}$ McFarlane (n 20).

${ }^{56}$ Ibid 81-82 (Lord Steyn).
} 
Lord Millett concluded that the choice was between no recovery on the basis that the benefits outweigh any loss and full recovery on the basis that the benefits must not be considered, as they are immeasurable. ${ }^{57}$ Lord Clyde rejected the benefits rule on the grounds that to require a parent to demonstrate that their child was 'more trouble than he or she is worth' is undesirable. ${ }^{58}$ Lord Slynn's reasoning for rejection was that it was too difficult to assess the benefits provided by a child. ${ }^{59}$ Lord Hope was of the opinion that considerations of fairness, justice and reasonableness required benefits to be taken into account, but that it was impossible to calculate such benefits. ${ }^{60}$

While McFarlane supports the conclusion of the Court of Appeal in $A C B$, the judicial approach in the former is arguably more conservative than that in $A C B$. Despite the decisive unanimity of the decision, there were substantial differences in the approaches taken by the Law Lords in McFarlane. Consequently, there was no single line of reasoning in the case. Lord Millet's analysis appeared to be policy-driven, whereas the other Law Lords subsumed the question of whether the upkeep costs should be recoverable under conventional principles, such as the existence of a duty of care and the categorisation of the claim as one for pure economic loss. Lord Millett admitted that, as a factual proposition, the birth of a child is a 'mixed blessing' since parenthood comes with its ups and downs; ${ }^{61}$ however, as a matter of legal policy, he held that 'society itself must regard the balance as beneficial'. ${ }^{62}$ According to Lord Millet, '[i]t is morally offensive to regard a normal healthy baby as more trouble and expense than it is worth' ${ }^{63}$ Allowing damages compensating for the wrong or injury arising from the birth of a healthy child is 'morally repugnant' and against public policy as the birth of a healthy child is a blessing and not a liability. ${ }^{64}$ Lord Millett further stressed

\footnotetext{
${ }^{57}$ Ibid 111 (Lord Millet).

${ }^{58}$ Ibid 103 (Lord Clyde).

${ }^{59}$ Ibid 75 (Lord Slynn).

${ }^{60}$ Ibid 97 (Lord Hope).

${ }^{61}$ Ibid 114 (Lord Millet).

${ }^{62}$ Ibid. In his reasoning, Lord Millet quoted Public Health Trust v Brown, 388 So 2d 1084, 1085-6 (Fla Ct App, 1980): 'a parent cannot be said to have been damaged by the birth and rearing of a normal, healthy child ... [I]t is a matter of universally-shared emotion and sentiment that the intangible but all-important, incalculable but invaluable "benefits" of parenthood far outweigh any of the mere monetary burdens involved ...': at 110-11.

${ }^{63}$ Ibid 114 (Lord Millet).

${ }^{64}$ Ibid 111.
} 
that the plaintiffs could not be allowed 'by a process of subjective devaluation, to make a detriment out of a benefit' ${ }^{65}$

The remaining Law Lords in McFarlane adopted a more conventional approach and arrived at their decision based on ordinary principles of the law of negligence. Lord Slynn, Lord Hope and Lord Steyn examined whether the defendant owed the plaintiffs a duty of care to avoid the costs associated with the raising of the child at issue. Lord Slynn concluded that there was no duty of care because it would not be 'fair, just or reasonable to impose on the doctor or his employer liability for the consequential responsibilities, imposed on or accepted by the parents to bring up a child' ${ }^{66}$ Lord Slynn rejected the policy argument that an award of damages might cause the child to be psychologically affected after he or she learned that his or her birth was unwanted. ${ }^{67}$ He contended that unplanned conception was not uncommon and that children born as a result of 'unwanted' pregnancies frequently became accepted, eventually, as part of their families. ${ }^{68}$ Lord Slynn also rejected the argument that an award of upkeep costs would result in medical practitioners encouraging patients to have abortions. In his opinion, the 'ethical standards of the medical profession (coupled with insurance)' provided sufficient protection against such a possibility. ${ }^{69}$ Lord Hope likewise concluded that it would not be 'fair, just or reasonable' for the upkeep claim to succeed. ${ }^{70}$ Lord Steyn utilised similar reasoning but framed his discussion using the concept of 'distributive justice' which, according to him, concerned the 'just distribution of burdens and losses among members of a society' ${ }^{71}$ An interesting aspect of Lord Steyn's discussion of the notion of distributive justice is that, though he had explicitly decried the reliance on policy considerations in deciding the case, one can still see the influence of policy in his judgment. ${ }^{72}$ For example, Lord Steyn stated: 'Instinctively, the traveller on the Underground would consider that the law of tort has no business to provide legal remedies consequent upon the birth of a healthy child, which all of us regard as a valuable and good thing, ${ }^{73}$

\footnotetext{
65 Ibid 112.

${ }^{66}$ Ibid 76 (Lord Slynn).

67 Ibid 75.

68 Ibid.

${ }^{69}$ Ibid.

${ }^{70}$ Ibid 97 (Lord Hope).

${ }^{71}$ Ibid 82 (Lord Steyn).

72 Ibid 83.

73 Ibid.
} 
Lord Clyde rejected the claim for upkeep costs because the restitution sought was disproportionate to the wrong done. ${ }^{74}$ His reasoning, in essence, was that awarding the costs of maintenance for a child who had been welcomed and accepted into the family did not accord with the idea of restitution. ${ }^{75}$ To allow the plaintiffs to enjoy the blessings of parenthood but be relieved of the obligations which it necessarily entails, would '[go] beyond what should constitute a reasonable restitution for the wrong done' ${ }^{76}$ Lord Clyde further made it clear that policy considerations in support of one party were usually balanced by a countervailing argument in support of the other party, and that such considerations were therefore not sufficient to provide a basis for decision-making. ${ }^{77}$ On the whole, while the decision in McFarlane was ostensibly made on the basis of conventional negligence principles, it is clear that notions of public policy were considered by the Law Lords, albeit not expressly as the basis of the judgment.

\section{B Australia}

In contrast, in Cattanach v Melchior ('Cattanach'), ${ }^{78}$ in a slim 4:3 majority decision, the High Court of Australia declined to follow the English position and awarded upkeep costs for the birth of a healthy but unwanted child in a wrongful conception case. In Cattanach, a sterilisation had been performed on only one fallopian tube, since the mother mistakenly believed her other tube had been removed when she was a child. The sterilising doctor had failed to investigate its presence and simply accepted the mother's assurance that her right fallopian tube had been removed. As a result, the plaintiffs had ceased using contraception, thinking they could not conceive and, because the right fallopian tube was in fact still present, the mother conceived and subsequently gave birth to a healthy child. The parents sued the sterilising doctor and the State of Queensland (the latter as responsible for the hospital where the sterilisation occurred). Pregnancy and upkeep costs were awarded at first instance $^{79}$ and upheld on appeal by the Queensland Court of Appeal. ${ }^{80}$ On

\footnotetext{
${ }^{74}$ Ibid 106 (Lord Clyde).

${ }^{75}$ Ibid 105.

${ }^{76}$ Ibid.

${ }^{77}$ Ibid 100.

${ }^{78}$ Cattanach (n 45).

${ }^{79}$ Melchior v Cattanach (2001) Aust Torts Reports $\llbracket[81-597$.

${ }^{80}$ Melchior v Cattanach (2001) 217 ALR 640.
} 
further appeal, the High Court confirmed that the upkeep costs were recoverable. ${ }^{81}$

The majority of the High Court - consisting of McHugh and Gummow JJ in a joint judgment, Kirby $\mathbf{J}$ and Callinan $\mathbf{J}$ - was not persuaded by the policy considerations against recovery. The majority held that the defendant could be held liable on the application of ordinary principles of negligence and that there should be no set-off between upkeep costs and emotional benefits, since these affect different interests. ${ }^{82}$ In the opinion of McHugh and Gummow JJ, the plaintiffs' loss was not 'the coming into existence of the parent-child relationship' but rather the expenditure that the plaintiffs had incurred or would incur in the future as a result of bringing up the 'unplanned' child. ${ }^{83}$ Therefore, " $[\mathrm{t}]$ he unplanned child is not the harm for which recompense is sought ... [I]t is the burden of the legal and moral responsibilities which arise by reason of the birth of the child that is in contention'. ${ }^{84}$ Since such expenditure was 'causally connected to the defendant's negligence' and 'the defendant [ought] to have reasonably foreseen that an expense of that kind might be incurred', it should therefore be recoverable. ${ }^{85}$ It is notable that McHugh and Gummow JJ described the language of 'wrongful birth' as diverting attention away from the relevant wrongful act — the negligence of the doctor. ${ }^{86}$

Kirby $\mathbf{J}$ similarly considered that it was not the birth of the child that constituted the injury for which the plaintiffs had sued; rather they had sued for the economic harm inflicted upon them by the injury they had suffered as a consequence of the doctor's negligence. ${ }^{87}$ Kirby $\mathrm{J}$ characterised the upkeep claim not as a claim for pure economic loss but for loss that was consequential upon the physical damage of unwanted pregnancy. ${ }^{88}$ Hence, under ordinary principles of tort liability, since the loss had resulted from the doctor's negligence, the burden of the loss fell on the doctor whose negligence was found to have caused the damage. ${ }^{89}$ Kirby $\mathbf{J}$ further cautioned against 'overwhelming legal analysis with emotion'. ${ }^{90}$ He noted that policy arguments

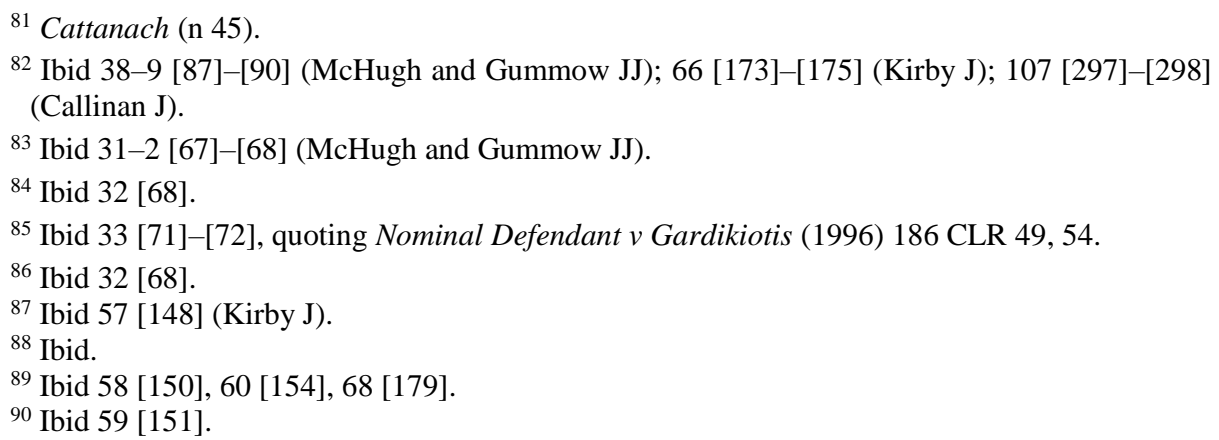


against full recovery, including those of the Cattanach minority (as discussed below), should be based on empirical evidence, not mere judicial assertion, which Kirby $\mathbf{J}$ noted had not been attempted in the case. ${ }^{91}$ Importantly, Kirby $\mathbf{J}$ observed that the award of damages did not necessarily entail a negative value judgment of the worth of the child..$^{92}$ Callinan J held that the plaintiff's economic loss was pure rather than consequential, commenting that the case was a 'relatively simple one' in which the requirements for pure economic loss had been met. ${ }^{93}$ Callinan $\mathrm{J}$ further found that the opposing policy arguments were unpersuasive. ${ }^{94}$ According to Callinan J, a judge's personal 'distaste' for assessing damages in an upkeep claim is no reason to decline such a claim if the application of legal principles allows recovery. ${ }^{95}$

The minority (consisting of Gleeson CJ, Hayne and Heydon JJ), however, found that the recovery of upkeep costs in this case conflicted with serious policy concerns. The most significant policy argument advanced by the minority was that the birth of a child was incapable of characterisation as a loss. Heydon J emphasised that 'human life is invaluable in the sense that it is incapable of valuation' and, consequently, the parenthood duty which flows from the arrival of new human life is also 'incapable of valuation or estimation or discharge by payment' ${ }^{96}$ Heydon $\mathbf{J}$ further put forth various policy arguments against recovery, arguing that the majority's view had failed to take into account the key values in family life and the type of litigation that would be likely to occur if recovery of upkeep costs were permitted. ${ }^{97}$ Hayne $\mathrm{J}$ considered that the benefits of parenthood must be taken into account in an assessment of damages, but that it would be hard to value the life of a child; hence the recovery of upkeep costs ought to be denied. ${ }^{98}$ Gleeson CJ viewed the actionable damage as the existence of the parent-child relationship arising from the wrongful conception, and considered such loss to be a pure economic loss arising out of a relationship that is incapable of valuation in financial terms. ${ }^{99}$ Gleeson CJ's reasoning focused on the difficulties

\footnotetext{
91 Ibid 59 [152].

92 Ibid 57 [148]; ACB 2017 (n 1) 958 [77).

${ }^{93}$ Ibid 107 [298], 107-8 [299] (Callinan J).

${ }^{94}$ Ibid 107-8 [299].

${ }^{95}$ Ibid 106-7 [296].

${ }^{96}$ Ibid 129 [356] (Heydon J).

${ }^{97}$ Ibid 117 [322].

${ }^{98}$ Ibid 74 [199]-[201] (Hayne J).

${ }^{99}$ Ibid 16 [25], 19 [30], 20 [33] (Gleeson CJ).
} 
associated with characterising the parent-child relationship as an injury capable of compensation. ${ }^{100}$

Two judges of the majority, namely McHugh and Gummow JJ, in disagreeing with the minority's policy arguments, pointed out that 'the relevant damage suffered by the Melchiors is the expenditure that they have incurred or will incur in the future, not the creation or existence of the parent-child relationship'. ${ }^{101}$ Importantly, the majority also rejected the notion that the birth of a healthy child is always a blessing for which parents should receive no compensation. Kirby $\mathbf{J}$ pointed out in Cattanach that this argument 'represents a fiction which the law should not apply to a particular case without objective evidence that bears it out'. ${ }^{102}$ The notion of 'blessing' is an amorphous one and involves questions of a subjective nature. For example, how can this 'blessing' be measured objectively and accurately? What are the exact benefits that constitute such a 'blessing'? Kirby J considered that the court is not the right forum for such value judgments. ${ }^{103}$ As a result, the majority's view also represents the rejection of the 'benefits' argument: that the costs and hardships associated with an unwanted pregnancy must be offset by the benefits which flow naturally from the birth and life of a healthy child and necessarily outweigh the costs and hardships. ${ }^{104}$

Another important policy argument in Cattanach (put forth by Heydon J) is that to allow a recovery of upkeep costs would encourage parents to act inconsistently with their parental duties by exaggerating the weaknesses and potential inadequacies of their children in order to maximise an award of damages. ${ }^{105}$ Similar to Heydon $\mathrm{J}$, Hayne $\mathrm{J}$ was concerned with the undesirability of allowing parents to exaggerate the burden created by their child and thereby to discount the role of parental responsibility. ${ }^{106}$ Gleeson CJ, having categorised the case as one of pure economic loss, ${ }^{107}$ also indicated that policy considerations weighed against the recovery of upkeep costs. ${ }^{108} \mathrm{He}$ warned of the potential indeterminacy of the liability for upkeep costs and accordingly considered that the recovery of upkeep costs should be denied

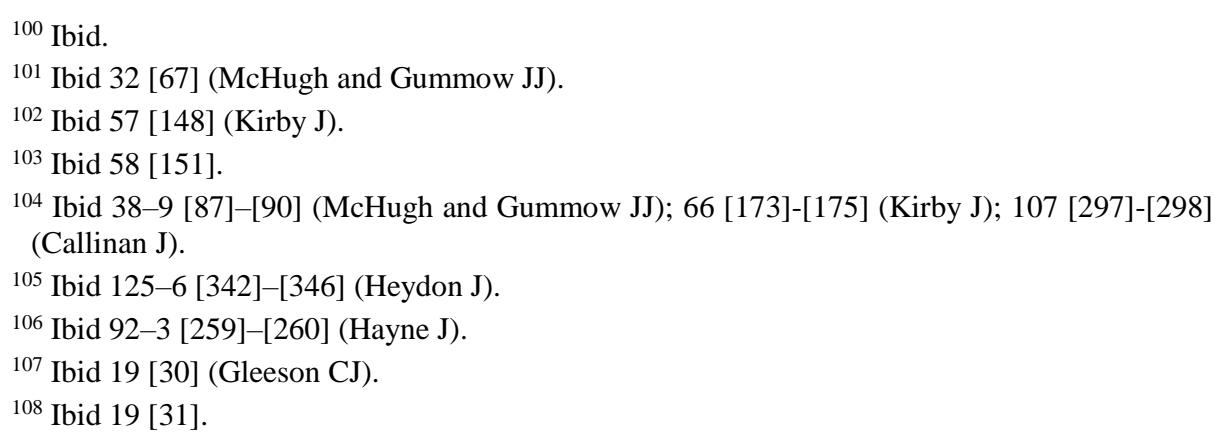


because normal tort principles do not permit recovery of indeterminate amounts for pure economic loss. ${ }^{109}$

The policies that were considered to conflict with an award of upkeep costs were variously expressed by the minority, but they generally related to the worth that is to be ascribed to the life of a person, and the worth that can be found in a parent-child relationship. According to Heydon J, it is 'morally offensive to regard a normal, healthy baby as more trouble and expense than it is worth'. ${ }^{110}$ Estimating a child's financial value to its parents is contrary to public policy because it treats the child as a 'commodity'. ${ }^{111}$ The life of the child has 'worth' in a sense quite distinct from the way commodities have 'worth' ${ }_{112}$ and the 'worth' of the child is incapable of financial estimation. ${ }^{113}$ The child would also be exposed to a considerable risk of harm if he or she were later to learn that the parents had in fact gone to court to get someone else to pay for the upkeep costs. ${ }^{114}$ A related policy argument put forth by the minority was that allowing recovery of upkeep costs would generate litigation which was bound to cause psychological harm in the later life of the child. ${ }^{115}$ These policy arguments were, however, not sufficiently persuasive to the majority. McHugh and Gummow JJ considered that more evidence and a clearer understanding were required concerning these matters before recovery could be precluded on such policy grounds. ${ }^{116}$ Kirby $\mathrm{J}$ also substantiated his objection, stating that '[i]t is difficult to accept that children in today's age learning such facts would not realise, if explained to them, that the claim was brought simply for the economic consequences of medical negligence'. ${ }^{117}$ Furthermore, Kirby $\mathrm{J}$ described the idea that parents would be forced to denigrate their children publicly in order to maximise economic benefit as 'sheer judicial fantasy'. ${ }^{118}$

The judges of the High Court in Cattanach openly discussed considerations of policy, though the majority was ultimately unpersuaded by the policy considerations raised. Importantly, the majority in Cattanach disapproved the reliance on policy considerations (as identified by the minority) to override

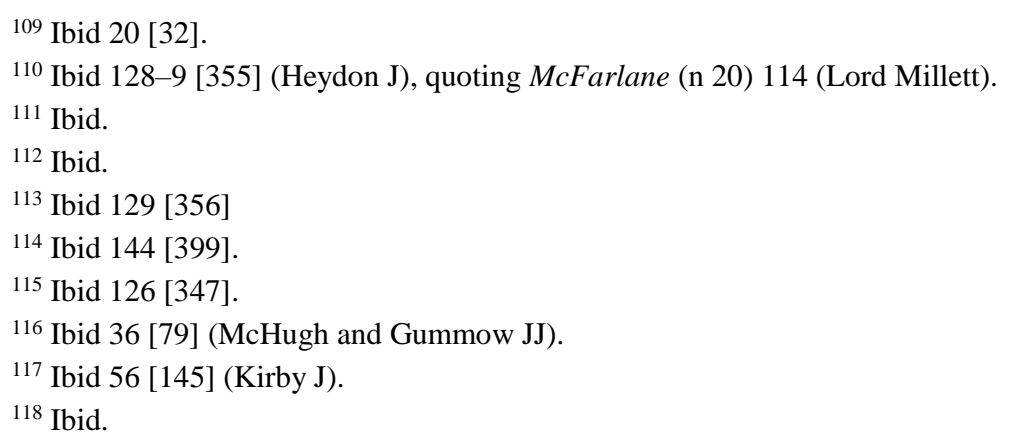


established principles of negligence. In particular, McHugh and Gummow JJ highlighted the danger of relying on policy considerations as justifications to award upkeep costs, stating that it is

a beguiling but misleading simplicity to invoke the broad values which few would deny and then glide to the conclusion that they operate to shield the appellants from the full consequences in law of [the defendant's] negligence. ${ }^{119}$

McHugh and Gummow JJ further indicated that 'the general considerations advanced by the appellants have not ... matured into a coherent body of legal doctrine'. ${ }^{120}$ Kirby $\mathbf{J}$ pointed out that a majority of the High Court had consistently rejected the 'explicit reference to policy ... in resolving novel questions of negligence liability' and, consequently, the use of policy in deciding the case should not be endorsed. ${ }^{121}$ Kirby $\mathrm{J}$ also spoke of the need for policy matters to be clearly enunciated if the application of ordinary legal principles is to be denied on the basis of public policy. ${ }^{122}$

Subsequently, three Australian States moved to pass legislation to reverse the decision of the High Court in Cattanach. ${ }^{123}$ In Queensland, where the case originated, legislation was swiftly introduced to prohibit the award of damages for the costs ordinarily associated with maintaining a child. ${ }^{124}$ The effect of the decision in Cattanach has also been qualified in New South Wales and South Australia which have enacted legislation to disallow recovery of upkeep costs, thereby effectively reversing this decision of the High Court of Australia. ${ }^{125}$ In the remaining states and territories of Australia, the legal principles expounded in Cattanach remain good law. ${ }^{126}$

\section{United States}

In the United States, recovery of upkeep costs is generally not permitted on public policy grounds. In Andrews $v$ Keltz ('Andrews'), a wrongful fertilisation case with facts similar to $A C B$, the New York Supreme Court held

\footnotetext{
${ }^{119}$ Ibid 35 [77] (McHugh and Gummow JJ).

${ }^{120}$ Ibid 30 [64].

${ }^{121}$ Ibid 49-50 [121] (Kirby J).

${ }^{122}$ Ibid 59 [152].

${ }^{123}$ ACB 2017 (n 1) 959 [80].

${ }^{124}$ Civil Liability Act 2003 (Qld) ss 49A and 49B(2).

${ }^{125}$ See s 71 of the Civil Liability Act 2002 (NSW); and s 67 of the Civil Liability Act 1936 (SA).

${ }^{126} A C B$ (n 1) 959-60 [80]; Fordham (n 16) 235.
} 
that public policy precluded recovery for the ordinary costs of raising a healthy child. ${ }^{127}$ In Andrews, a native Dominican mother and a Caucasian father had undergone IVF to have a child who would be biologically their own. The plaintiff mother gave birth to a girl who was healthy, but who had skin, facial and hair characteristics different from both of the parents. It was subsequently discovered that the clinic had negligently used sperm other than the sperm of the plaintiff's husband. The mother's claim for upkeep costs was denied on public policy grounds. The Court did not, however, elaborate on its policy reasons for precluding recovery of the upkeep costs other than by making reference to its previous decisions in wrongful conception cases. ${ }^{128}$ One such decision was O'Toole $v$ Greenberg, in which the New York Supreme Court had stated: " $\mathrm{t}$ ]o hold that the birth of a healthy child represents a legal harm would be to engage this court in the jurisprudentially improper task of recasting the immutable, intrinsic value of human life according to the financial burden thus imposed upon the parents'. ${ }^{129}$ Recognising the "“very nearly uniform high value" which the law and mankind have placed upon human life, ${ }^{130}$ the New York Supreme Court concluded that 'it cannot be said, as a matter of public policy, that the birth of a healthy child constitutes a harm cognizable at law'. ${ }^{131}$ The New York Supreme Court in Andrews further made reference to Weintraub v Brown ('Weintraub'). ${ }^{132}$ The question to be resolved in that case was whether the parents of an unwanted, but otherwise healthy and normal, child may recover the ordinary costs of raising that child as damages resulting from the defendants' negligence in the performance of a surgical birth control procedure. The New York Supreme Court in Weintraub concluded the following:

As matter of public policy we are unable to hold that the birth of an unwanted but otherwise healthy and normal child constitutes an injury to the child's parents and is, therefore, compensable in a medical malpractice action. Such a holding would be incompatible with contemporary views concerning one of life's most precious gifts — the birth of a normal and

\footnotetext{
127 Andrews (n 49) 944. Another case involving wrongful fertilisation was Leeds Teaching Hospitals NHS Trust v A [2003] EWHC 259 (QB), however the issue in that case was the legal parentage of the child and not recovery of upkeep costs: see $A C B 2017$ (n 1) 939 [32].

${ }^{128}$ Andrews (n 49) 943-5. The New York Supreme Court merely held itself to be bound by the principles established by existing case law, namely O'Toole $v$ Greenberg 64 NY2d 427 (NY Sup Ct, 1985) ('O'Toole') and Weintraub v Brown 98 AD 2d 339 (NY Sup Ct, 1983) ('Weintraub') which were both wrongful conception cases.

${ }^{129}$ O'Toole (n 128) 433-4.

${ }^{130}$ Ibid 433, quoting Becker v Schwartz, 46 NY2d 401, 411 (NY Sup Ct, 1978).

${ }^{131}$ Ibid 433.

${ }^{132}$ Weintraub (n 128).
} 
healthy child. We are loath to adopt a rule, the primary effect of which is to encourage, indeed reward, the parents' disparagement or outright denial of the value of their child's life. ${ }^{133}$

\section{South Africa}

Recovery of upkeep costs in wrongful conception cases has, however, been allowed in South Africa. In Administrator, Natal $v$ Edouard, the Appellate Division of South Africa upheld a decision of a lower court awarding damages to the plaintiff for upkeep costs, but denying a claim for pain and suffering. ${ }^{134}$ In that case, the plaintiff had sought damages from the defendant hospital for the costs of raising a healthy child born subsequent to a failed sterilisation. The Appellate Division upheld the award of upkeep costs on the basis that the hospital whose negligence had brought about such an undesired birth ought to be liable for all the expenses that went along with raising that child, being expenses that the parents would not have incurred had it not been for the negligence of others. ${ }^{135}$ Furthermore, the Appellate Division also saw no basis for believing that such recovery would interfere with the sanctity of the parent-child relationship. It did, however, limit the recovery of upkeep costs to a situation where the parents were suffering economic hardship (which the Appellate Division found not to be the case here). ${ }^{136}$

The Appellate Division's detailed explanation ${ }^{137}$ for its rejection of the appellant's policy arguments is worth some discussion here. First, in response to the policy argument that the birth of a healthy child cannot be regarded as a legal wrong, the Appellate Division clarified that the wrong is not the unwanted birth, but the negligence of others that led to financial loss. Second, the appellant had argued that the financial burden of having to maintain a child is outweighed by the benefits of parenthood; hence it was argued that the birth of a child is a blessing on the whole. The Appellate Division rejected the argument, stating that there is no legal basis in South Africa to require nonpecuniary benefits to be offset against the plaintiff's loss. The law requires a set off only in a case of tangible benefits, such that tangible benefits accruing as a result of a breach of contract or the commission of a tort are set off against the loss suffered by a plaintiff. Third, the Appellate Division

\footnotetext{
${ }^{133}$ Ibid 348-9.

${ }^{134}$ Administrator, Natal v Edouard [1990] 3 SA 581 (Appellate Division).

135 Ibid.

${ }^{136}$ Ibid.

${ }^{137}$ Ibid. See also LC Coetzee, 'Legal Liability for Failure to Prevent Pregnancy (Wrongful Pregnancy)' (2017) 107(5) South Africa Medical Journal 394, $396<$ https://pdfs.semantic scholar.org/eab2/0fd4008fc67cb4e36ea3829c05da3eb64642.pdf>.
} 
further rejected the policy argument that it would be highly undesirable for any child to learn that a court had publicly awarded damages to his or her parents because the child's birth was a mistake. The Appellate Division reasoned that the possibility of the child finding out about the judgment in his or her later life was remote. Lastly, the Appellate Division also disagreed with the view that an award of damages for upkeep costs would transfer the obligation to support and maintain the child from its parents to the defendant. In particular, the Appellate Division did not consider that such recovery interferes with the sanctity accorded by law to the parent-child relationship. According to the Appellate Division, the award of damages does not extinguish the parents' obligation to maintain the child, but at best enables them to fulfil it.

\section{Policy Considerations in ACB}

Ultimately, the Court of Appeal in $A C B$ held that the claim for upkeep costs should be disallowed on public policy grounds and that the public policy concerns in relation to a recovery of upkeep costs remained the same, regardless of whether the action was in contract or in tort. ${ }^{138}$ The Court of Appeal further created a new tort by allowing the plaintiff to recover for the loss of genetic affinity. In $A C B$, although the Court of Appeal expressly based its decision on public policy considerations, it was silent on whether the reliance on policy grounds in its judicial reasoning was appropriate and justified. As seen in the decision in McFarlane, although notions of public policy were considered in the case, ultimately the Law Lords preferred to rest their decision on conventional negligence principles. Further, in Cattanach, the majority strongly objected to the use of policy considerations as the basis for its decision. In the words of Kirby $\mathrm{J}$ in this case,

[j]udges ... have no authority to adopt arbitrary departures from basic doctrine ... Least of all may they do so, in our secular society, on the footing of their personal religious beliefs or 'moral' assessments concealed in an inarticulate premise dressed up, and described, as legal principle or

\footnotetext{
${ }^{138}$ For a further discussion on why the outcome of disallowing upkeep costs did not differ in contract, see $A C B 2017$ (n 1) 969-71 [102]-[105]. See also Tom Foxton, 'Inaccurate Conception: ACB v Thomson Medical' (2018) 81(2) Modern Law Review 337, 344-5. The Court of Appeal in $A C B$, however, left open the question on the recovery of upkeep costs in a situation where there had been a contractual warranty guaranteeing a particular outcome and where the contract had expressly provided for the recovery of such a head of damages: see ACB 2017 (n 1) 971 [105].
} 
legal policy. ${ }^{139}$

This raises the question of whether the Court of Appeal in $A C B$ had the legal authority to base its decision on public policy considerations and, consequently, whether the decision in $A C B$ runs contrary to the long-standing view that there is little room for public policy reasoning in private law adjudication. This issue is discussed below and the view is taken that the Court of Appeal's decision in $A C B$ was correctly made.

\section{A Role of Public Policy in Judicial Decisions}

The core of the concept of public policy is that it involves arguments about the public or common good. However, the reliance on policy considerations in judicial decision-making has been a controversial topic. Public policy has long been regarded as an elusive concept. Burrough $\mathrm{J}$ in Richardson v Mellish famously described it as a 'very unruly horse, and when once you get astride it you never know where it will carry you' ${ }^{140}$ Courts often face the difficult interplay between law and public policy in the determination of a particular case. Moreover, courts are wary of relying on public policy in judicial reasoning because it is often seen as a 'cover for uncertain reasoning'. ${ }^{141}$

The objection to reliance on public policy in judicial decision-making is attributed to two main factors. ${ }^{142}$ First, the logic of public policy cuts against the logic of the judicial adjudication, especially in cases involving a dispute between private individuals. ${ }^{143}$ Whereas public policy focuses on what is good for the public or common good, the purpose of judicial adjudication is to correct the injustice between the parties in the particular dispute. ${ }^{144}$ Hence, if viewed in that context, public policy arguments which deal with the common good are not relevant to the arguments concerning the justice of the particular case that is before the court. Second, what is or is not for the public or

\footnotetext{
${ }^{139}$ Cattanach (n 45) 53 [137] (Kirby J) (citations omitted).

140 [1824] 130 ER 294, 303.

${ }^{141}$ James D Hopkins, 'Public Policy and the Formation of a Rule of Law' (1971) 37 Brooklyn Law Review 323, 333.

142 Sundaresh Menon CJ, 'Taming the Unruly Horse: The Treatment of Public Policy Arguments in the Courts' (Speech, Kota Kinabalu, 19 February 2019) <https://www.supremecourt.gov.sg/Data/Editor/Documents/Public\%20Policy\%20Lecture\%2 0-\%2019Feb2019.pdf>.

${ }^{143}$ UKM v Attorney General [2019] 3 SLR 874, 923 [108] ('UKM'); Ross Grantham and Darryn Jensen, 'The Proper Role of Policy in Private Law Adjudication' (2018) 68(2) University of Toronto Law Journal 187, 191.

${ }^{144}$ UKM (n 143) 923 [108].
} 
common good is often not a matter of complete consensus and changes with the times. ${ }^{145}$ Thus, '[p]ublic policy does not admit of definition and is not easily explained ... [P]ublic policy is a variable quantity ... [I]t must vary and does vary with the habits, capacities, and opportunities of the public'. ${ }^{146}$ Accordingly, in using policy considerations in judicial decision-making, courts should justify their taking into account the common good when adjudicating a dispute between private parties, and their reliance on such policy considerations as an authoritative or persuasive basis for their ruling. What these justifications are would depend on the legal context of the case before the court.

Public policy arguments permeate every area of the law, including tort law, albeit in different ways and to different degrees. They may also be used to justify the existence and scope of a claimed right. For example, when the court is deciding whether to recognise a new tort, it considers whether doing so would be justified by considerations of public policy. ${ }^{147}$ The challenge of public policy is that it requires courts to balance the common good and individual justice. Society is changing faster than laws can adapt. Rapid developments in technology have created possibilities for medical treatment and procedures that raise complex moral and ethical issues. Reproductive negligence, which was in issue in $A C B$, is one example. Other areas frequently involving moral and ethical dilemmas include commercial surrogacy ${ }^{148}$ and same-sex marriages.

The matter of addressing public policy considerations was once again before the Singapore High Court when it decided the recent case of UKMv AttorneyGeneral ('UKM'), ${ }^{149}$ involving an application by a Singaporean gay man to adopt his biological son who was conceived using the applicant's sperm and the egg of an anonymous donor, and then birthed by a surrogate mother in the United States. In allowing the applicant's adoption of his son, the Singapore High Court carefully threaded the needle to conclude that it was in the child's

\footnotetext{
145 Ibid 923 [109].

${ }^{146}$ Davies v Davies (1887) 36 Ch D 359, 364 (Kekewich J), quoted in UKM (n 143) 923 [109].

${ }^{147}$ Menon (n 142).

${ }^{148}$ Generally, there are two types of commercial surrogacy. Traditional surrogacy involves artificially inseminating the surrogate's own egg with the intended father's (or a donor's) sperm. Gestational surrogacy involves the surrogate carrying a baby that is conceived through fertilising the egg of the intended mother or a donor with the intended father's (or a donor's) sperm: Tan Seow Hon, 'Should Commercial Surrogacy Be Legalised?' Straits Times (online, 17 January 2018) <http://ink.library.smu.edu.sg/sol_research/2547>.

${ }^{149} U K M$ (n 143). For a further discussion of UKM, see Tan Seow Hon, 'Surrogacy, Child's Welfare, and Public Policy in Adoption Applications: UKM v Attorney-General' [2019] Singapore Journal of Legal Studies 263.
} 
interests to be adopted by the applicant. While the outcome of this particular case may be worth celebrating, the broader significance of the judgment is that the Singapore High Court took the opportunity to discuss the role of public policy in judicial reasoning and set out a structured approach towards the treatment of public policy arguments in the courts. Under this approach, the two factors — 'type of law' and 'type of public policy' - form a matrix of legal contexts. ${ }^{150}$ The first axis - resting on the distinction between judgemade law and statutory law - identifies the constitutional constraints upon judicial policy-making, whereas the second axis - resting on the distinction between socio-economic policy and legal policy — identifies practical constraints placed on judicial policy-making. ${ }^{151}$ Generally, legal policy involves arguments about the common good that relate to the conduct and consequences of legal practice, whereas socio-economic policy involves arguments about what would be good for society, especially from a social, economic, cultural and political perspective. ${ }^{152}$ Depending on where a case is placed in this matrix, the court will face a combination of constitutional and practical constraints on its ability to rely on public policy considerations in its judicial decision-making.

$A C B$ is a case involving judge-made law, and the public policy in question is socio-economic in nature. For this reason, the court may, as a general rule, rest its decision on public policy, subject to the constraints of precedent, established principles, and the analogical reasoning of the common law. ${ }^{153}$ In this context, the court has effectively been delegated the responsibility for making and changing the law, and therefore must adjudicate matters not only with the individual case in view, but also with the common good in mind. ${ }^{154}$ The court's power to establish the law on the basis of public policy considerations is, however, limited in at least three ways. ${ }^{155}$ First, the 'bipolar structure of the private law' requires the court to reconcile any community interests that it takes into consideration with the need to do justice between the disputing parties. ${ }^{156}$ Second, the principles established by the court remain subject to legislative overruling. ${ }^{157}$ Third, the court may in an appropriate case

\footnotetext{
${ }^{150}$ UKM (n 143) 924 [111].

${ }^{151}$ Ibid.

152 Ibid.

${ }^{153}$ See UKM (n 143) 924 [112]. See also Andrew Robertson, 'Constraints on Policy-Based Reasoning' in Andrew Robertson and Tang Hang Wu (eds), The Goals of Private Law (Hart Publishing, 2009) ch 11.

${ }^{154}$ UKM (n 143) 924 [112].

${ }^{155}$ Ibid.

${ }^{156}$ Ibid. See also Robertson (n 153).

${ }^{157}$ UKM (n 143) 924 [112].
} 
decide that a change in the law would represent such a significant development that legislative action would be more appropriate than judicial lawmaking. ${ }^{158}$

\section{B Policy Considerations in Denying Upkeep Costs}

In $A C B$, the Court of Appeal was persuaded by two main policy arguments in denying upkeep costs.

\section{The Obligations of Parenthood}

The Court of Appeal reasoned that '[ $t$ ]he obligation to maintain one's child is an obligation at the heart of parenthood and cannot be a legally cognisable head of loss'. ${ }^{159}$ The Court of Appeal rejected the argument that the upkeep claim is maintainable simply on the application of the conventional principles of civil liability, which was the majority view in Cattanach. In Cattanach, the High Court of Australia had viewed a claim for upkeep costs as similar in principle to a claim for damages for pain and suffering, since the former can be considered as the last link in the concatenation of obligation, breach, causation, foreseeability and damage that forms the chain of civil liability in the law of negligence. ${ }^{160}$ The Court of Appeal in $A C B$, however, adopted a different view, clarifying that the case was in essence

not about the direct consequences to the [plaintiff] qua patient of the physical and other aspects of pregnancy and birth; rather, it is about the consequences to the [plaintiff] qua mother of the existence of the child and the concomitant creation of a relationship pursuant to which there are legal, moral, and social obligations to care for, support, and nurture Baby P. ${ }^{161}$

Importantly, the Court of Appeal focused more broadly 'on the notion of parenthood as an institution' arising out of the relationship between a parent and a child. ${ }^{162}$ At the core of this relationship lies each parent's 'independent and non-derogable duty to maintain his/her children, whether directly, through the provision of such necessities as the child may need, or indirectly, by contributing to the cost of providing such necessities'. ${ }^{163}$

\footnotetext{
${ }^{158}$ Ibid.

${ }^{159}$ ACB 2017 (n 1) 962 [86].

${ }^{160}$ Cattanach (n 45).

${ }^{161}$ ACB 2017 (n 1) 962-3 [87] (emphasis in original). See generally Todd (n 15) 532.

${ }^{162}$ ACB 2017 (n 1) 963 [88].

${ }^{163}$ Ibid 963 [89], quoting AUA v ATZ [2016] 4 SLR 674, 688 [40].
} 
When upkeep claims are pursued, relief is sought in respect of the parental duty to maintain the child, and their success therefore necessarily depends on the recognition of parenthood obligations as actionable damage. ${ }^{164}$ However, this was not a logical step that the Court of Appeal in $A C B$ was prepared to take. The duty to maintain one's child lies at the very heart of parenthood and thus expenses associated with the discharge of this parenthood duty are not capable of characterisation as a loss. ${ }^{165}$ Importantly, the Court of Appeal emphasised that this was a 'normative claim about the paradigm of family relationships which exists in the law'166 and 'the meaning of legal parenthood'. ${ }^{167}$ In the words of Phang JA, parenthood comprises 'an indivisible bundle of rights and obligations which cannot be peeled away and hived off à la carte ... [T] he obligations of parenthood are fundamental, indivisible, and incapable of sounding in damages'. ${ }^{168}$ Notably, Phang JA reasoned that the plaintiff could not argue, on the one hand, that she and her husband had accepted Baby $\mathrm{P}$ as their own and yet, on the other hand, be allowed to argue that they could not accept the obligation of maintaining the child. ${ }^{169}$ Ultimately, the Court of Appeal in $A C B$ was unconvinced by the argument (which courts such as the High Court in Cattanach had relied upon) that what was counted as loss was not the unplanned child per se, but the unplanned and unwanted financial expenses arising from the child's birth. The Court of Appeal reasoned that, while such an argument might be a possible answer to the objection that the upkeep claim results in the denigration of the worth of the child, it is not an adequate justification for overriding the notion that no parent can claim a legal entitlement to be free from the responsibilities of parenthood, whether financial or otherwise. ${ }^{170}$

\section{Inconsistency with the Nature of the Parent-Child Relationship}

Recovery of upkeep costs would also be 'fundamentally inconsistent with the nature of the parent-child relationship and would place the [plaintiff] in a

\footnotetext{
${ }^{164} A C B 2017$ (n 1) 963 [87]; see also English and Hafeez-Baig (n 33).

${ }^{165}$ ACB 2017 (n 1) 964 [90].

${ }^{166}$ Ibid 964 [90] (emphasis in original).

${ }^{167}$ Ibid 965-6 [93].

${ }^{168}$ Ibid (emphasis in original).

${ }^{169}$ Ibid. The duty to maintain one's child is also enshrined in s 68 of the Women's Charter (Singapore, cap 353, 2009 rev ed): at 963-64 [89]. Section 9 of the Status of Children (Assisted Reproduction Technology) Act (Singapore, cap 317A, 2015 rev ed) prescribes rules to determine the legal parenthood and status of children conceived where the wrong egg, sperm or embryo was used in an assisted reproduction fertilisation procedure. Pursuant to this Act, in $A C B$, the plaintiff's husband was deemed to be the legal parent of Baby $\mathrm{P}$.

${ }^{170} A C B 2017$ (n 1) 966 [94].
} 
position where her personal interests as a litigant would conflict with her duties as a parent'. ${ }^{171}$ The Court of Appeal noted that, to pursue such a claim, parents would have to testify in court that their child represented a net loss to them. This would encourage the 'exaggeration of any infirmities and the diminution of benefits as might exist in their children'. ${ }^{172}$ In the event that recovery were to be permitted, then one would need to decide if some form of set-off would need to be made for the benefits brought by the child. It should be noted that, in Singapore, children have a legal obligation pursuant to the Maintenance of Parents Act ${ }^{173}$ to financially support their parents in old age. Consequently, if some form of off-setting were to be done, then the "unseemly spectacle of parents disparaging the "value" of their children or the degree of their affection for them in open court' would seem a real possibility. ${ }^{174}$ Such a situation would clearly be inconsistent with the parent-child relationship. ${ }^{175} \mathrm{It}$ would also lead to the undesirable outcome that 'little or no damages would be awarded for loving mothers and fathers while generous compensation would be obtained by those who disparage and reject their child' ${ }^{176}$ The Court of Appeal further noted that even if off-setting were disallowed, this would at most prevent parents from downplaying the benefits which their children bring; however, the fact would remain that parents may still have the incentive to emphasise the detriments brought about by the child in order to maximise the award of damages. ${ }^{177}$ The Court of Appeal was of the view that such possibilities were not merely fanciful concerns. Allowing recovery of an upkeep claim was therefore held to be 'fundamentally at odds with the overarching duty that parents have to provide, care for, and love their children'. ${ }^{178}$

\footnotetext{
${ }^{171}$ Ibid 962 [86].

${ }^{172}$ Ibid 966-7 [95].

${ }^{173}$ Maintenance of Parents Act (Singapore, cap 167B, 1996 rev ed).

${ }^{174}$ ACB 2017 (n 1) 968-9 [99], quoting Public Health Trust v Brown, 388 So 2d 1084, 1086 (Schwartz J) (Fla Ct App, 1980).

175 In $A C B$, the Court of Appeal was silent on the public policy concern that an award of damages for upkeep costs may detrimentally affect the child's psychological well-being as the child finds out the circumstances of his or her birth. On this issue, one possible solution put forth by Fred Norton was to permit parents to maintain actions anonymously or pseudonymously: Fred Norton, 'Assisted Reproduction and the Frustration of Genetic Affinity: Interest, Injury, and Damages’ (1999) 74(3) New York University Law Review 793, 817.

176 Melchior v Cattanach (2001) 217 ALR 640 [169] (Thomas JA) (Queensland Court of Appeal).

${ }^{177}$ ACB 2017 (n 1) 969 [100].

${ }^{178}$ Ibid 966-7 [95].
} 


\section{Policy Considerations in Compensating Loss of Genetic Affinity}

In $A C B$, the Court of Appeal embarked on an extensive analysis of the concept of an award for loss of autonomy but ultimately did not recognise loss of autonomy as an actionable interest in its own right, though it acknowledged the relevance of autonomy as an important background consideration. ${ }^{179}$ The Court of Appeal viewed the concept of autonomy, being the loss of the opportunity to live the life one has planned, as being 'too nebulous and too contested a concept to ground a claim' ${ }^{180}$ The Court of Appeal noted that the plaintiff did suffer a severe dislocation of her reproductive plans, constituted principally by the 'fracture of biological parenthood'; 181 however, it considered that to classify the damage simply as a 'loss of autonomy' would be too general. ${ }^{182}$ Furthermore, the Court of Appeal's reluctance to recognise the plaintiff's loss as a form of loss of autonomy was due to the concern that such recognition would 'undermine existing control mechanisms which keep recovery in the tort of negligence within sensible bounds'. ${ }^{183}$

The question then is whether some other forms of loss might be recoverable. Up till this point, it would seem that the Court of Appeal's rejection of the upkeep claim without more had failed to recognise that a substantial real harm had been done, leaving the plaintiff with no remedy other than the damages for pain and suffering. ${ }^{184}$ Such an outcome would not correct the injustice suffered by the plaintiff. Importantly, rejecting the upkeep claim on public policy grounds without granting further relief to the plaintiff runs contrary to what the 'bipolar structure of the private law' achieves, that is, to reconcile any community interests that it takes into consideration with the need to do justice between the disputing parties. ${ }^{185}$ The Court of Appeal's decision to allow the novel claim based on loss of genetic affinity therefore is a legallyjustified, fair and viable approach, providing adequate compensation to the deserving plaintiff in $A C B$, while taking into account the public policy concerns associated with the recovery of upkeep costs. Genetic affinity is an entirely new standard, and the Court of Appeal ought to be commended for compellingly justifying the recognition of the value put on biological

\footnotetext{
${ }^{179}$ Ibid 980 [125].

${ }^{180}$ Ibid 976 [115].

${ }^{181}$ Ibid 980 [126].

182 Ibid.

${ }^{183}$ Ibid 976 [115], 979 [123]-[124].

${ }^{184}$ ACB 2015 (n 1) 228 [17].

${ }^{185}$ UKM (n 143) 925 [112].
} 
relationships and taking into account good and persuasive policy considerations. ${ }^{186}$

\section{$1 \quad$ Loss of Chance to Have a Family Structure Which Comports with Her Aspirations}

In $A C B$, the Court of Appeal identified the real loss suffered by the plaintiff as the loss of chance 'to have a family structure which comports with her aspirations'. ${ }^{187}$ Importantly, such loss involves the loss of the ordinary human experience of a parent sharing ties of blood and physical traits with the child. ${ }^{188}$ The choice to undergo IVF is often motivated by a 'deeply felt longing for a child of one's own' ${ }^{189}$ Ethicist Leon Kass has described this longing as 'a couple's desire to embody, out of the conjugal union of their separate bodies, a child who is flesh of their separate flesh made one'. ${ }^{190}$ Having one's own child can be narrowly interpreted to mean having one's own genetic material in the offspring ${ }^{191}$ but it also suggests an older concept called consanguinity, which is defined as 'kinship; blood relationship; the connection or relation between persons descended from the same stock or common ancestor'. ${ }^{192}$ In other words, the notion of genetic affinity goes beyond correct or desired genetic mix, and should be viewed broadly to include the personal and cultural significance of genetic or biological connections with one's offspring. This could cover the following parental desires. ${ }^{193}$ First, a couple desiring genetic affinity may wish their children to be literal, physical manifestation of the parental union. Second, it could be that the couple desires to have children who share a common ancestry with the parents, particularly where that shared ancestry is of deep cultural significance. Lastly, the desire to have children with whom one shares physical traits may reflect a desire to undergo the 'normal' parenthood experience. ${ }^{194}$ These desires are met through what can be collectively referred

\footnotetext{
186 See generally Todd (n 15) 146.

${ }^{187}$ ACB 2017 (n 1) 981-2 [130].

${ }^{188}$ ACB 2017 (n 1) 981 [128].

189 Norton (n 175) 802.

190 Leon R Kass, Life, Liberty and the Defense of Dignity: The Challenge for Bioethics (Encounter Books, 2002) 96.

191 See Leon R Kass, 'The Wisdom of Repugnance: Why We Should Ban the Cloning of Humans' (1998) 32(2) Valparaiso University Law Review 679, 692: 'Flesh of their flesh, the child is the parents' own commingled being externalized and given a separate and persisting existence.'

192 Black's Law Dictionary (West Publishing Co, 6 $6^{\text {th }}$ ed, 1990) 303.

193 Norton (n 175) 802-3.

194 Ibid 803.
} 
to as 'genetic affinity', and the Court of Appeal in $A C B$ rightly concluded that the loss suffered by the plaintiff was the result of a 'complex amalgam of biological, social, ethical, and historical factors'. ${ }^{195}$ In $A C B$, the Court of Appeal further clarified the fact that the interest in genetic affinity not only involves the ties between the parents and the child, but also the parents' relationship with their extended relations; the child's relationship with his/her siblings; as well as the family's relationship with the wider community. ${ }^{196}$

Nonetheless, the Court of Appeal in $A C B$ was careful to clarify that it was not laying out a 'prescriptive definition of what a family should be' nor setting out 'to denigrate adoption' which would not involve genetic or biological connectedness. ${ }^{197}$ Often, persons who consciously choose to undergo IVF do so 'because of a deep desire to experience, as far as possible, the ordinary experience of parenthood'. ${ }^{198}$ This was exactly what the plaintiff in $A C B$ had been denied due to the negligence of others, and the plaintiff's loss, resulting in the fracture of biological parenthood, was rightly identified by the Court of Appeal as a legal wrong that ought to be compensated at law.

However, the characterisation of the damage as loss of genetic affinity could well be open to challenge. Arguably, the ruling in $A C B$ could be taken broadly to mean that recovery of loss is possible in a scenario where a woman desired to undergo IVF with sperm from a donor of her choosing (not her husband), but instead conceived with sperm from a different donor. In such a case, it may be argued that the woman's interest in having a child with the particular donor ought to be legally recognised and protected. This raises a complication as courts in Singapore may in future have to assess which familial aspirations are worthy of legal protection. This is particularly so given the outcome in UKM in which the Singapore High Court allowed a Singaporean gay father's appeal to adopt his biological son conceived and carried by a surrogate mother. $U K M$ effectively allowed the father to bring up his son in a family unit with his long-term same-sex partner. In the light of $U K M$ (but remaining faithful to the law's recognition and protection of marriage as an institution), one must wonder whether the $A C B$ decision might be taken to mean that courts in Singapore would adopt a more liberal view of what 'familial aspirations' entail. It would be interesting to see further case law development in this area.

\footnotetext{
${ }^{195}$ ACB 2017 (n 1) 984 [135].

${ }^{196}$ Ibid 981 [128]. The Court's reasoning could well mean that the siblings and grandparents of Baby $\mathrm{P}$ could also bring a claim against the defendant clinic.

${ }^{197}$ Ibid 981 [129].

198 Ibid.
} 
Another aspect of the $A C B$ judgment that is open to challenge is the Court of Appeal's suggestion that the plaintiff had an interest in maintaining the integrity of her reproductive plans. ${ }^{199}$ Specifically, the Court reiterated that the plaintiff's right to have a child with her husband to 'maintain an intergenerational genetic link' and to maintain 'affinity' should be recognised under the law. ${ }^{200}$ On this basis, it would appear that the interest in genetic affinity also includes an interest in maintaining the integrity of a person's reproductive plans. This raises the question of whether the Court is effectively protecting the plaintiff's right to choose the person with whom she plans to have a child. ${ }^{201}$ The Court of Appeal, however, left open the question of whether claimants in future wrongful birth and wrongful conception cases could potentially sue for damages on the basis that their interest in maintaining their reproductive plans ought to also be legally protected.

\section{$2 \quad$ Profound Social and Emotional Consequences}

In identifying the harm suffered by the plaintiff in $A C B$, the Court of Appeal also recognised the profound social and emotional consequences arising from Baby P's lack of any genetic link to the plaintiff's husband. ${ }^{202}$ The lack of legal precedents in the area of wrongful fertilisation meant that the Court of Appeal in $A C B$ had to draw on cases in the broader category of wrongful births that had discussed the significance of 'affinity' in their judgment. The most notable case was the Northern Irish case of $A$ and $B$ by $C$ (their mother and next friend) v $A$ - Health and Social Services Trust (' $A$ and $B$ '), a case involving wrongful fertilisation. ${ }^{203}$ In $A$ and $B$, the plaintiffs were twins born from a negligently performed IVF, resulting in them having darker skin than their parents and different skin colours from each other as well. The plaintiffs subsequently sued for damages, on the basis that, as a result of their different skin colours, they had to endure 'abusive and derogative comment and hurtful name calling from other children,' which led them to suffer from emotional distress. ${ }^{204}$ At first instance, Gillen $\mathbf{J}$ dismissed the suit on the ground that a difference in skin colour could not constitute a legally recognisable form of actionable damage. ${ }^{205}$ Gillen $\mathrm{J}$ explored the policy considerations that would

\footnotetext{
199 Ibid 984 [135].

${ }^{200}$ Ibid.

${ }^{201}$ See, eg, English and Hafeez-Baig (n 33).

${ }^{202}$ ACB 2017 (n 1) 984 [136].

${ }^{203} A$ and $B$ by $C$ (their mother and next friend) $v A-$ Health and Social Services Trust [2011] NICA 28 ('A and B 2011'); A (A Minor) and B (A minor) by $C$ (Their Mother and Next Friend) v A Health and Social Services Trust [2010] NIQB 108 ('A and B 2010').

${ }^{204} A$ and $B$ 2010 (n 203) [5].

${ }^{205}$ Ibid [31]-[32], [34].
} 
be involved if compensation were to be awarded to the plaintiffs. As expressed by Gillen J, '[i]n a modern civilised society the colour of their skin - no more than the colour of their eyes or their hair or their intelligence or their height - cannot and should not count as connoting some damage to them'. ${ }^{206}$ Furthermore, it is important that 'children of all colours, shapes and sizes must be afforded equality of opportunity free from the burdens of racial or ethnic discrimination'. ${ }^{207}$ Accordingly, the High Court of Northern Ireland concluded that the award of damages would be contrary to the policy considerations underlying a multi-cultural society. ${ }^{208}$ On appeal, the decision was upheld by the Northern Ireland Court of Appeal on the same basis that a difference in skin colour could not constitute a form of actionable damage. ${ }^{209}$

While the Court of Appeal in $A C B$ agreed with the outcome in $A$ and $B$, it appeared to suggest that the claim in $A$ and $B$, if crafted differently, might have allowed the recovery of damages on the basis of 'profound social and emotional consequences which will persist for years to come' as a result of the difference in the children's skin colour from their parents'. ${ }^{210}$ This approach would recognise the 'true harm that was suffered' by the plaintiffs in $A$ and $B .^{211}$ However, the particular kinds of physical and/or racial traits that the parents might desire or not desire would appear to be the very characteristics that would constitute illegitimate grounds of discrimination. ${ }^{212}$ In this regard, the Court of Appeal in $A C B$ was careful not to condone racism but recognised that it is a social reality in Singapore that needed to be faced (since Singapore is not yet to be considered a post-racial society). ${ }^{213}$ In $A C B$,

\footnotetext{
${ }^{206}$ Ibid [18].

${ }^{207}$ Ibid [23].

${ }^{208}$ Ibid [23]-[25]. Gillen J stated: '[i]t would be contrary to the principles which underlie our multi-cultural society to suggest that the genes they carry somehow render them "a victim" at the hands of the defendant. These children do not carry the seal of the fault of the defendants. Their colour bestows no disadvantage upon them for which they can receive recompense': at [23].

${ }^{209} A$ and $B 2011$ (n 203) [9]-[10]. See also Sally Sheldon, 'Only Skin Deep? The Harm of Being Born a Different Colour to One's Parents: $A$ (a minor) and B (a minor) by $C$ (their mother and next friend) $v$ A Health and Social Services Trust [2010] NIQB 108; [2011] NICA 28' (2011) 19(4) Medical Law Review 657, 663.

${ }^{210}$ ACB 2017 (n 1) 983 [133], 984 [136].

${ }^{211}$ Ibid 983 [133] (emphasis in original).

${ }^{212}$ Norton (n 175) 810.

${ }^{213} A C B 2017$ (n 1) 983-4 [134]. In support of this point, the Court of Appeal quoted the statement made by the Constitutional Commission chaired by Sundaresh Menon CJ in respect of race, as follows: 'Singapore cannot yet be considered a post-racial society: this is a reality that must be faced, even if it is one that is not to be endorsed': Report of the Constitutional Commission 2016 (17 August 2016) [5.15].
} 
part of the plaintiff's claim concerned the stigma and misunderstanding that she and her husband would face due to Baby P having Indian blood and a markedly different complexion from them. The Court of Appeal emphasised that the recognition of a racial component in its judgment was not intended as 'judicial sanction for any partiality for single-race families' but rather as an acknowledgment of the 'complex role that physical resemblance, race, and cultural and ethnic identity' play in 'individual well-being'. ${ }^{214}$ Nonetheless, one may still wonder whether the damages might have been different if the defendant clinic had instead mistakenly used the sperm of a donor of the same race as the plaintiff's husband. This leaves open the question of how much physical and/or racial traits should be factored into the assessment of damages. In hindsight, might it have been less controversial if the Court of Appeal had drawn less attention to the racial component in $A C B$ ?

\section{$3 \quad$ Significance of Genes}

By allowing the claim for a loss of genetic affinity, the Court of Appeal in $A C B$ also necessarily affirmed that genes do play a role in determining a child's personal identity and traits. Although it has been said that the public has limited knowledge regarding genetics, ${ }^{215}$ past studies show that people tend to readily offer genetic explanations to explain people's behaviours. ${ }^{216}$ People also tend to believe that traits with a genetic basis are immutable. ${ }^{217}$ It has also been said that people's understanding of genetics influences the way they live their lives, resulting in a strong emphasis placed by society on genetic relatedness. ${ }^{218}$ This is essentially the 'nature' versus 'nurture' debate propounded by Professor Norton. ${ }^{219}$ Questions about the degree to which genetic factors genuinely influence personal traits remain the subject of

\footnotetext{
${ }^{214}$ ACB 2017 (n 1) 983-4 [134].

215 Esther Lim Rui Hsien, 'Does the Claim for Loss of Genetic Affinity Have Any Place in United States Jurisprudence?' (2019) 67(1) Drake Law Review 59; Lanie et al, 'Exploring the Public Understanding of Basic Genetic Concepts' (2004) 13(4) Journal of Genetic Counselling 305, 313.

${ }^{216}$ See Roxanne L Parrot et al, 'Development and Validation of Tools to Assess Genetic Discrimination and Genetically Based Racism' (2005) 97(7) Journal of National Medicine Association 980, 981; Sara Shostak et al, 'The Politics of the Gene: Social Status and Beliefs about Genetics for Individual Outcomes’ (2009) 72(1) Social Psychology Quarterly 77, 89.

217 See Victoria Brescoll and Marianne LaFrance, 'The Correlates and Consequences of Newspaper Reports of Research on Sex Differences' (2004) 15(8) Psychological Science 515, 520.

${ }^{218}$ Ilan Dar-Nimrod and Steven J Heine, 'Genetic Essentialism: On the Deceptive Determinism of DNA' (2011) 137(5) Psychological Bulletin 800, 801.

${ }^{219}$ Norton (n 175) 812-13.
} 
controversy. ${ }^{220}$ If desired characteristics are not genetically influenced, but rather influenced by environmental factors, it would undermine the legitimacy of placing any significance on genes in determining a person's traits.

The judgment in $A C B$ also occurs at an interesting juncture in an era where constant advances in the area of genomics and procreative technologies are gaining traction in the medical field. In 2015, the United Kingdom became the first country to legalise Mitochondrial Genome Replacement Technology ('MGRT'), ${ }^{21}$ sometimes called 'three-parent IVF', which focuses on the prevention of the transmission of mitochondrial disorders from a mother to her child. MGRT substitutes the faulty DNA in a mother's egg with healthy DNA from a healthy donor. While the United Kingdom has permitted the use of MGRT in clinical research, the technology is not allowed in most other countries, including Australia, New Zealand, Singapore and the United States. ${ }^{22}$ In $A C B$, the Court of Appeal did not extend its reasoning to expressly recognise a right to genetic affinity. However, given its recognition of an interest in genetic affinity, one can put forth a plausible argument that the prohibition of the use of 'three-parent IVF' violates individuals' procreative rights, grounded in individuals' interest in genetic affinity. ${ }^{223}$ Further, in a jurisdiction that allows MGRT, what if, for example, a mother, upon finding out that she had a severe mitochondrial disease, underwent the 'three-parent IVF' to prevent transmission of her particular faulty DNA to her child, but it failed? Could the mother institute an action for the child's genes being incorrect, and hence the loss of genetic affinity?

The same argument may also be made in the context of surrogacy. Currently, entering a surrogacy contract is not a criminal offence in Singapore, and there are no sanctions against contracting with a surrogate either in Singapore or overseas. ${ }^{224}$ However, medical institutions and professionals in Singapore are prohibited from offering surrogacy arrangements. ${ }^{225}$ In light of $U K M$ and with the recognition of an interest in genetic affinity in $A C B$, one may similarly

\footnotetext{
${ }^{220} \operatorname{Lim}$ (n 215) 70: 'While there is an indisputable correlation between genes and our physical traits, the strength of this correlation may vary.'

${ }^{221}$ See James Gallagher, 'UK Approves Three-Person Babies', BBC News (Web Page, 24 February 2015) < https://www.bbc.com/news/health-31594856>.

222 Owen Schaefer and Markus Labude, 'Genetic Affinity and the Right to "Three-Parent IVF"' (2017) 34(12) Journal of Assisted Reproduction and Genetics 1577, 1577.

${ }^{223}$ Ibid $1578-9$.

${ }^{224}$ For a discussion of whether commercial surrogacy should be legalised, see Tan (n 148).

${ }^{225}$ Ministry of Health, Singapore, Licensing Terms and Conditions on Assisted Reproduction Services (26 April 2011) [5.48.b] promulgated under s 6(5) of the Private Hospitals and Medical Clinics Act (Singapore, cap 248, 1999 rev ed).
} 
make a plausible argument that the prohibition of surrogacy arrangements violates individuals' procreative rights, and hence their interest in having genetic affinity with their children. If an interest in genetic affinity is to be valued, a woman who faces a risky pregnancy or is unable to carry a pregnancy should be allowed to engage a gestational carrier who will then carry the child to full term. In such a case, the child will be born with the parents' genes, and the gestational carrier has no biological relation to the child.

\section{Conclusion}

In what was described as 'one of the most difficult cases' that had come before the Singapore Court of Appeal, $A C B$ has raised mixed reactions and debate. However, overall the judgment delivered by the Court of Appeal has more merits than flaws and is to be commended. Indeed, taking into account all the circumstances, the Court of Appeal has taken a legally justified and pragmatic approach to the issues raised by the case, relying on policy considerations to underscore the fundamental importance of biological relationships, and ensuring that adequate remedies can be awarded to deserving plaintiffs in cases of medical negligence in the provision of IVF. 